\title{
EFISIENSI DI BANK SYARIAH: STUDI EMPIRIS PADA UNIT USAHA SYARIAH BANK PEMBANGUNAN DAERAH DI INDONESIA
}

\author{
Lili Puspita Sari \\ Universitas Pembangunan Nasional Veteran Jakarta \\ Jl. RS. Fatmawati Raya, Pd. Labu, Kec. Cilandak, Kota Depok, Jawa Barat 12450 \\ Email: lilipuspitasari@upnvj.ac.id \\ Hendri Tanjung \\ Universitas Ibn Khaldun Bogor \\ Jl. K.H. Sholeh Iskandar Raya Km. 2, Kedung Badak, Bogor 16161, Jawa Barat \\ Email: hendri.tanjung@gmail.com
}

\begin{abstract}
This study aims to evaluate Sharia Unit of Regional Development Bank (Bank Pembangunan Daerah) perform in Indonesia period 2012-2017. Considering the development of UUS in Indonesia including BPD, this research seeks to analyze the bank performs considering the BPD. BPD have important role to support the regional economy. One of the indicators used to know about bank perform is efficiency. The input variables used in this research are Third Party Fund, Labor Cost, Total Financing and Other Bank Placements. Using Data Envelopment Analysis (DEA) method, we found out that the efficiency level of UUS BPD in Indonesia is quite good with an average efficiency level above $85 \%$. Meanwhile, by using tobit regression, we known that all variables used significantly influence the perform of UUS BPD efficiency level in Indonesia.
\end{abstract}

Keywords: Efficiency, DEA, Tobit Regression

\begin{abstract}
ABSTRAK
Penelitian ini bertujuan untuk mengevaluasi tingkat efisiensi Unit Usaha Syariah Bank Pembangunan Daerah di Indonesia periode 2012-2017. Memperhatikan perkembangan UUS di Indonesia termasuk BPD, penelitian ini berusaha untuk melihat sejauh mana kinerja bank tersebut mengingat BPD memiliki peran penting dalam membantu ekonomi daerah. Salah satu indikator yang digunakan yaitu tingkat efisiensi menggunakan pendekatan dari sisi teknis. Variabel yang digunakan pada penelitian ini yaitu Dana Pihak Ketiga (DPK), Biaya Tenaga Kerja, Total Pembiayaan dan Penempatan Bank Lain dengan menggunakan sampel 12 Unit Usaha Syariah Bank Pembangunan Daerah di seluruh Indonesia. Dengan menggunakan metode Data Envelopment Analysis (DEA) didapatkan hasil bahwa tingkat efisiensi UUS BPD di Indonesia sudah cukup baik dengan tingkat rata-rata efisiensi diatas $85 \%$. Sementara dengan menggunakan regresi tobit, diketahui semua variabel yang digunakan berpengaruh signifikan terhadap pencapaian tingkat efisiensi UUS BPD di Indonesia.
\end{abstract}

Kata kunci: Efisiensi, DEA, Regresi Tobit 


\section{PENDAHULUAN}

Perbankan sebagai sebuah entitas industri keuangan, memiliki pengaruh yang besar berjalannya kegiatan perekonomian di suatu negara. Stabilnya kinerja perbankan menjadi hal penting yang harus dijaga dikarenakan memiliki pengaruh yang cukup fundamental. Pengaruh ini terlihat dari berjalannya kegiatan atau aktivitas ekonomi masyarakat agar tetap tumbuh dan terus berkembang. Di sisi lain, timbal balik yang didapatkan oleh bank yaitu keuntungan ataupun kerugian dikarenakan ini berkaitan dengan kegiatan bisnis.

Jika berbicara tentang bank, tentu tidak dapat dipisahkan dengan kegiatan penghimpunan dana maupun penyaluran dana kepada masyarakat ataupun perusahaan. Salah satu instrumen informasi untuk mengetahui bagaimana kinerja suatu perusahaan termasuk bank dengan menggunakan laporan keuangan. Berdasarkan laporan keuangan, kita dapat mengetahui kinerja atau aktivitas perbankan dalam suatu rentang periode tertentu. Tujuan yang ingin dicapai yaitu apakah bank tersebut dapat memenuhi target-target yang diinginkan atau justru sebaliknya.

Dewasa ini, pendekatan yang dipergunakan dalam melakukan pengukuran kinerja perbankan yaitu melalui perhitungan efisiensi (Putri \& Lukviarman, 2008). Kinerja perbankan sangat identik bagaimana bank sebagai sebuah lembaga bisnis di industri keuangan dapat memaksimalkan potensi yang dimiliki untuk menghasilkan keuntungan sebesar-besarnya (Isik \& Hassan, 2002). Hal ini dapat diartikan bahwa perbankan diharapkan dapat efisien dalam hal melakukan kegiatan bisnis akan tetapi tidak mengurangi keuntungan di masa mendatang. Kondisi ini sangat wajar mengingat bank merupakan entitas bisnis yang tentu memiliki tujuan untuk menghasilkan keuntungan seperti perusahaan pada umumnya.

Di Indonesia, eksistensi dunia perbankan sangat kuat. Pemerintah bersama Bank Sentral maupun otoritas terkait sangat aktif dalam memantau keadaan industri perbankan. Pencegahan terhadap resiko yang mungkin ditimbulkan menjadi alasan ketatnya pengawasan industri perbankan di Indonesia. Banyaknya bank yang hadir menjadi permasalahan klasik bagi industri perbankan itu sendiri. Kompetisi yang semakin ketat, tentu membuat setiap bank berlomba-lomba dalam menjaga eksistensinya agar tidak terjadi kebangkrutan di kemudian hari.

Bank syariah sedang mengalami masa periode tersebut. Ditengah persaingan ketat industri perbankan di Indonesia, bank syariah dihadapkan pada bagaimana menjaga eksistensinya agar mampu bertahan dan tidak terjadi crash. Ditengah lesunya ekonomi global, tentu berdampak terhadap secara tidak langsung terhadap industri perbankan termasuk bank syariah. Sebagai sebuah entitas bisnis, bank dihadapkan agar mendapatkan keuntungan yang tinggi dari dana-dana yang didapat dari para deposan. Tentunya ini terkait dengan keuntungan yang harus dibagikan oleh bank kepada para deposan sebagai bagian dari imbalan bagi para deposan yang bersedia menitipkan uangnya di bank. 
Untuk mengatasi hal tersebut, efisiensi merupakan langkah riil yang dapat dilakukan suatu bank ditengah situasi ekonomi yang saat ini tidak menentu. Hal ini juga berlaku bagi bank agar dapat terus bersaing dengan bank konvensional. Mengingat pangsa pasar muslim terbesar di dunia, tentunya sangat disayangkan jika bank syariah tidak mampu memanfaatkan potensi besar tersebut. Jika bank syariah tidak mampu bertahan maka secara tidak langsung keberlangsungan industri perbankan syariah di Indonesia akan terancam hilang. Maka dari itu, efisiensi menjadi sesuatu hal mutlak yang harus dilakukan bank syariah jika ingin tetap menjaga eksistensinya dalam industri perbankan (Sufian, 2007),

Seperti yang dijelaskan sebelumnya, tujuan dari efisiensi yaitu untuk mencapai tujuan yang diinginkan instansi yaitu keuntungan yang setinggitingginya dengan keterbatasan sumber daya yang ada. Sebelum melakukan efisiensi, pihak bank tentu perlu mengetahui sejauh mana kegiatan bisnis perbankan tersebut berjalan.

Apakah sudah berada di koridor yang tepat atau terdapat kesalahan dalam implementasi di lapangan. Ketika terjadi kesalahan tentu akan berdampak pada menurunnya tingkat keuntungan yang didapatkan. Imbasnya bank akan mengalami penurunan terutama dari sisi aset. Bank syariah tentu menyadari hal tersebut, maka dari itu efisiensi menjadi suatu kewajiban yang harus dilakukan.Perkembangan perbankan syariah di tanah air belum menunjukkan hasil yang memuaskan. Dengan pangsa pasar yang tidak beranjak dari $5 \%$ bahkan cenderung turun membuat para regulator harus bekerja ekstra lebih keras dalam membantu mempertahankan eksistensi bank yang berlandaskan pada syariah tersebut.

Tentu selain dukungan dari regulator, pihak perbankan syariah sendiri harus melakukan evaluasi secara khususnya mengenai kinerja dari sisi bisnis. Inilah kenapa efisiensi mutlak diperlukan karena sebagai tolak ukur sejauh mana perkembangan perbankan syariah terutama dari segi bisnis. Setidaknya masyarakat mendapatkan gambaran mengenai bagaimana progress dari perkembangan perbankan syariah khususnya dari sisi bisnis mengingat para nasabah tentu selain agama, motivasi menabung di bank syariah yaitu pembagian profit.

Dewasa ini perhatian banyak orang banyak tertuju kepada perkembangan Bank Umum Syariah (BUS) dan Unit Usaha Syariah (UUS). Ini dikarenakan dua jenis bank ini merupakan motor utama dalam mendukung untuk meningkatkan market share perbankan syariah.Dalam penelitian ini, peneliti tertarik untuk melihat perkembangan dari UUS mengingat institusi keuangan ini masih memiliki dukungan dari bank induk yaitu bank konvensional. Tentu dengan asumsi awal bahwa UUS bisa berkembang lebih baik karena mendapat dukungan dari bank induk baik dari segi modal maupun layanan kantor. Untuk membuktikan asumsi tersebut, maka peneliti akan mengawali dengan memberikan data mengenai bagaimana pergerakan total aset dan Dana Pihak Ketiga (DPK)

Total aset dan DPK bisa menjadi indikator bagaimana laju pertumbuhan sebuah institusi keuangan. Dalam hal ini perkembangan dua indikator tersebut juga dapat memberikan gambaran bagi kita bagaimana 
keadaan perkembangan UUS di Indonesia. Selain itu ini juga sebagai bagian dari bahan evaluasi bagaimana sebenarnya kinerja institusi tersebut serta perbaikan apa yang harus segera dilakukan agar ke depannya kinerjanya semakin baik lagi.

Tabel 1. Total Aset dan DPK UUS Per Maret 2018 (Rp Miliar)

\begin{tabular}{lrrrrrrr}
\hline & Sep'2017 & Okt'2017 & Nov'2017 & Des'2017 & Jan'2018 & Feb'2018 & Mar'2018 \\
\hline $\begin{array}{l}\text { Total } \\
\text { Aset }\end{array}$ & 119.148 & 122.445 & 123.447 & 136.154 & 128.789 & 128.870 & 133.934 \\
\hline DPK & 86.225 & 89.167 & 89.959 & 96.495 & 95.866 & 92.685 & 95.089 \\
\hline
\end{tabular}

Sumber: Statistik Perbankan Syariah OJK Per Oktober 2018 (Diolah)

Dari data terbaru yang didapatkan, terlihat total aset dari UUS dalam rentang waktu September 2017 hingga Maret 2018 mengalami fluktuasi. Titik tertinggi dari total aset yang didapat berada di bulan Desember 2017 yaitu sebesar Rp 136 Triliun. Sementara dari sisi total DPK, pergerakannya cenderung naik, hanya terjadi penurunan selama Desember 2017-Februari 2018 namun Maret 2018 kembali naik. Berdasarkan Data tersebut dapat identifikasi bahwa UUS di Indonesia perlu melakukan akselerasi dalam hal peningkatan kinerja. Artinya bahwa melihat adanya fluktuasi baik dari sisi aset maupun DPK dapat dijadikan dasar untuk melihat sejauh mana sebenarnya UUS menjalankan konsep efisiensi dalam hal menjalankan kegiatan mereka.

Di sisi lain, kita ketahui bank UUS di Indonesia yang dimiliki induk yang berasal dari Bank Umum (milik pemerintah dan swasta) maupun Bank Pembangunan Daerah (BPD). Kedua insitusi tersebut tentu memiliki perbedaan dari segi modal maupun jaringan kantor. Pada konteks BPD, dukungan modal dan jaringan masih terbatas, sehingga berpengaruh terhadap kinerja yang kurang optimal misalnya dari segi efisiensi (Endri \& Abidin, 2009).

Untuk itu, pengukuran efisiensi UUS di bawah BPD juga perlu dilakukan sebagai temuan informasi bagaimana kinerja unit tersebut saat ini. Sebagai bagian dari ekosistem industri perbankan syariah di Indonesia, informasi kinerja UUS BPD penting untuk mengetahui sejauh mana unit tersebut bekerja secara optimal dalam mendukung pengembangan keuangan syariah.

\section{TELAAH TEORITIS}

Efisiensi merupakan salah satu indikator yang digunakan untuk mengetahui bagaimana kinerja perbankan. Dengan tingkat efisiensi yang semakin tinggi mengidikasikan bank tersebut memiliki kinerja yang baik, begitu pun sebaliknya. Dalam melakukan pengukuran tersebut, ada tiga pendekatan umum yang biasa digunakan yaitu teknis, biaya dan profit.Penelitian ini lebih berfokus dalam meneliti tingkat efisiensi Bank Pembangunan Daerah (BPD) Syariah dengan pendekatan teknis. Peneliti melakukan review beberapa 
jurnal yang meneliti tentang efisiensi di perbankan pada umumnya, dan BPD pada khususnya.

Penelitian yang dilakukan oleh Yudistira (2004) meneliti tentang efisiensi perbankan syariah dengan menggunakan pendekatan teknis. Metode yang digunakan pada penelitian ini menggunakan DEA dengan populasi yang digunakan sebanyak 18 bank syariah dari 12 negara berbasis mayoritas muslim termasuk Indonesia. Periode yang digunakan pada penelitian dari tahun 1997 hingga tahun 2000. Sementara itu untuk pemilihan variabel input yang digunakan pada penelitian ini yaitu biaya tenaga kerja, DPK dan total aset. Sementara untuk variabel output yang digunakan yaitu total pembiayaan, pendapatan lainnya serta aset lancar. Hasil penelitian memperlihatkan tingkat efisiensi bank syariah di luar timur tengah periode 1997 hingga 1999 lebih baik dibandingkan bank syariah yang berada di timur tengah. Sementara untuk tahun 2000 tingkat efisiensi bank syariah di timur tengah jauh lebih baik dibandingkan bank syariah yang berada di luar timur tengah.

Ascarya dan Yumanita (2006) meneliti tentang efisiensi bank syariah di Indonesia dengan menggunakan pendekatan dari sisi teknis. Metode yang digunakan pada penelitian ini yaitu DEA dengan periode penelitian yang digunakan yaitu dari tahun 2002 hingga 2008.Populasi yang digunakan pada penelitian ini yaitu 4 BUS dan 6 UUS sehingga secara keseluruhan terdapat 10 sampel. Untuk variabel input yang digunakan pada penelitian ini yaitu total aset, DPK dan biaya tenaga kerja. Di sisi lain, untuk variabel output yang digunakan yaitu total pembiayaan, pendapatan lainnya dan aktiva lancar. Hasil penelitian memperlihatkan bahwa dengan pendekatan efisiensi teknis, skor efisiensi yang didapatkan oleh bank syariah cukup baik dimana ada beberapa BUS yang mampu mencapai skala efisiensi hingga mencapai $100 \%$. Hal ini memperlihatkan bank syariah di Indonesia memiliki performa yang cukup baik.

Hartono, Djohar, \& Daryanto (2008) melakukan analisis efisiensi terhadap Bank Pembiayaan Rakyat di daerah Jabodetabek periode 2005-2007 dengan menggunakan pendekatan teknis. Dengan menggunakan metode Data Envelopment Analysis (DEA) serta variabel input terdiri dari Dana Pihak Ketiga (DPK), Biaya Tenaga Kerja dan Aktiva Tetap serta Output yang terdiri dari Total Pembiayaan dan Pendapatan lainnya. Hasil penelitian memperlihatkan bahwa BPR belum efisiensi dengan nilai rata-rata efisiensi di kisaran 50-60\%.

Abidin dan Endri (2009) mengkaji tingkat efisiensi di Bank Pembangunan Daerah (BPD) seluruh Indonesia periode 2006-2007 dengan pendekatan teknis menggunakan metode DEA. Variabel input yang digunakan DPK, biaya tenaga kerja dan aktiva tetap serta output yang digunakan yaitu total pembiayaan dan total pendapatan. Hasil penelitian memperlihatkan selama periode tersebut BPD yang berada di pulau Jawa memiliki tingkat efisiensi paling baik dengan rata-rata tingkat efisiensi diatas $85 \%$. Diikuti BPD yang berada di pulau Sumatera, Kalimantan, Sulawesi dan terakhir Papua. 
Fathony (2013) menjelaskan efisiensi perbankan nasional berdasarkan ukuran bank dengan metode DEA. Populasi pada penelitian ini terdiri dari 115 Bank Umum Konvensional yang tercatat di Bank Indonesia. Variabel Input yang dipergunakan yaitu : DPK, Biaya Tenaga Kerja dan Aktiva Tetap. Sementara Variabel Output yang digunakan yaitu Total Kredit dan Total Pendapatan. Skala ekonomi memberikan keuntungan bagi bank berupa biaya rata-rata per-unit yang rendah dengan jumlah pinjaman yang semakin besar. Bagi bank yang tingkat efisiensinya belum mencapai optimal dapat melakukan potensi perbaikan (potential improvement) dengan meningkatkan output dan/atau menurunkan input dengan mengacu (benchmarking) pada pada bank yang efisien.

Penelitian yang dilakukan Firdaus dan Hosen (2013) meneliti tentang efisiensi bank syariah di Indonesia dengan menggunakan efisiensi teknis. Metode yang digunakan pada penelitian yaitu DEA dan populasi yang dipakai yaitu 10 BUS yang beroperasi di Indonesia dengan periode penelitian 2010 hingga 2012. Untuk variabel input yang digunakan pada penelitian ini yaitu total aset, biaya tenaga kerja dan DPK. Sementara di sisi lain, variabel output yang digunakan pada penelitian ini yaitu total pembiayaan dan pendapatan operasional. Peneliti juga menggunakan regresi tobit dalam menganalisis variabel-variabel mana yang berpengaruh terhadap tingkat efisiensi bank syariah.

Hasil penelitian memperlihatkan rata-rata efisiensi BUS di Indonesia cukup baik dengan sampel bank yang mampu meraih skor bagus yaitu Bank Muamalat. Sementara bank-bank syariah memiliki tingkat skor efisiensi teknis yang cenderung bergerak secara fluktuatif. Dengan menggunakan regresi tobit, diketahui bahwa variabel-variabel total aset dan DPK berpengaruh positif signifikan terhadap tingkat efisiensi teknis bank. Sementara variabel total pembiayaan memiliki pengaruh negatif dan signifikan terhadap tingkat efisiensi bank.

Tuzuhroh (2014) meneliti tentang efisiensi Bank Umum Syariah (BUS) di Indonesia Periode 2010-2012. Metode yang digunakan dalam penelitian ini yaitu DEA, dimana populasi sampel yang ditentukan terdiri dari 11 BUS yang beroperasi di Indonesia. Variabel input yang digunakan terdiri dari simpanan dan beban operasional lainnya. Sementara untuk variabel output terdiri dari pembiayaan (O1) dan pendapatan operasional lainnya $(\mathrm{O} 2)$. Berdasarkan hasil analisis, didapatkan hasil jika sebagaian besar bank syariah selama periode 2010 sampai dengan tahun 2012 belum efisien Penyebab terjadinya inefisiensi pada BUS-BUS tersebut bersumber dari kurangnya optimalnya bank dalam mengoptimalkan sumber pendanaan menjadi output (pembiayaan dan pendapatan operasional lainnya).

Gishkori dan Ullah (2013) meneliti tentang perbandingan efisiensi bank konvensional dan bank syariah di Pakistan periode 2007 hingga 2011 dengan pendekatan efisiensi teknis. Metode yang digunakan pada penelitian ini yaitu DEA. Sampel bank yang digunakan sebanyak 34 bank. Variabel input yang digunakan pada penelitian ini terdiri dari total asset yang digunakan, DPK dan jumlah tenaga kerja. Sementara variabel output yang digunakan pada penelitian ini yaitu penempatan pada bank lain dan total 
pembiayaan. Peneliti juga menggunakan regresi tobit dalam mengidentifikasi variabel mana yang berpengaruh signifikan terhadap tingkat efisiensi teknis bank.

Hasil efisiensi memperlihatkan bahwa rata-rata efisiensi bank di Pakistan baik konvensional maupun syariah masih cukup rendah. Nilai efisiensi terbesar justru bank asing yang beroperasi di Pakistan seperti Citibank dengan skor sebesar $83,9 \%$. Sementara bank lokal hanya memiliki skor efisiensi rata-rata dibawah 50\%.Berdasarkan penggunaan regresi tobit, diketahui bahwa penempatan pada bank lain, DPK, total pembiayaan, total aset yang digunakan memiliki pengaruh positif dan signifikan terhadap tingkat efisiensi teknis bank. Sementara variabel jumlah tenaga kerja berpengaruh negatif dan signifikan terhadap tingkat efisiensi bank.

Cahya (2015) tentang Efisiensi Kinerja Bank Umum Syariah Di Indonesia Tahun 2010 - 2012 dengan menggunakan metode DEA. Populasi Penelitian yang ditentukan pada penelitian ini terfokus pada seluruh Bank Umum Syariah (BUS) yang berada di Indonesia yaitu 11 BUS. variabel Input yang dipergunakan pada penelitian ini yaitu : DPK dan Biaya Tenaga Kerja. Sementara variabel output yang digunakan pada penelitian ini yaitu Total Pembiayaan dan Pendapatan Operasional.

Berdasarkan dari analisis yang telah dilakukan dari kinerja 11 bank Umum Syariah (BUS) di Indonesia pada tahun 2010- 2012 terdapat 4 BUS yang belum efisien dan 7 Bank Umum Syariah lainnya telah mencapai tingkat efisiensi. Dapat disimpulkan mayoritas Bank Umum Syariah di Indonesia telah efisien. Beberapa hal yang menyebabkan masih adanya bank yang belum efisien diantaranya kinerja bank yang tidak optimal dalam mengolah sumber daya yaitu dana pihak ketiga menjadi pembiayaan. Hal ini tercermin dari realisasi output pembiayaan dan pendapatan operasional yang rendah sehingga berpengaruh terhadap pengukuran skor efisiensi yang rendah.

Edward dan Anwar (2015) meneliti tentang Efisiensi Perbankan Syariah Di Indonesia Periode 2010-2013. Populasi Penelitian yang ditentukan pada penelitian ini yaitu 8 Bank yang termasuk Bank Umum Syariah (BUS) yang beroperasi di Indonesia. Pemilihan BUS didasarkan pada ketersediaan data yang dapat memudahkan bagi peneliti. Sampel dari BUSBUS yang digunakan yaitu Bank Syariah Mandiri, Bank BNI syariah, Bank BRI Syariah, Bank BJB Syariah, Bank Panin Syariah, Bank Syariah Bukopin, Bank BCA Syariah dan Bank Muamalat Indonesia.

Variabel Input yang dipergunakan yaitu : DPK dan Modal disetor. Sementara Variabel Output yang digunakan yaitu Total Pembiayaan yang dilakukan mencakup pembiayaan Mudharabah, Musyarakah, Murabahah, Istishna, Ijarah dan Qardh. Hasil penelitian menunjukkan rata-rata efisiensi teknis tertinggi selama tahun 2010 sampai dengan 2013 diperoleh oleh Bank Syariah Mandiri sebesar 99,38\%. Di sisi lain nilai efisiensi teknis yang paling terendah didapatkan oleh BRI Syariah dengan nilai sekitar 51,90\% Sementara dengan menggunakan pendekatan efisiensi biaya, selama tahun 2010 sampai dengan tahun 2013 rata-rata nilai efisiensi tertinggi masih didapatkan oleh 
Bank Mandiri Syariah dengan nilai sebesar 79,24\%. Sementara nilai efisiensi terendah kembali didapatkan oleh BRI Syariah dengan nilai 39,11\%.

Hasil dari penelitian juga menjelaskan bahwa skala usaha secara signifikan berpengaruh positif dengan tingkat. efisiensi biaya bank-bank syariah. Ini berarti bahwa semakin besar skala usaha bank syariah maka semakin efisien bank syariah tersebut. Di sisi lain hasil penelitian yang didapatkan peneliti sesuai dengan penelitian Rangan (1998). Model ini yaitu variable skala usaha hanya mampu menjelaskan sebesar $18,5 \%$ dari tingkat efisiensi biaya sedangkan sisanya dijelaskan oleh variabel lainnya.

Faisol, Zainuri dan Yulianti (2015) tentang efisiensi perbankan syariah di Indonesia pasca krisis Finansial Global 2008 menggunakan metode DEA. Populasi Penelitian yang ditentukan pada penelitian ini yaitu 11 Bank Umum Syariah dan 12 Unit Usaha Syariah (termasuk Bank Pembangunan Daerah) dengan periode penelitian 2010-2014.Variabel input yang dipergunakan pada penelitian ini yaitu : Biaya Tenaga Kerja, Aset Tetap dan Total Deposito. Di sisi lain, variabel output yang digunakan pada penelitian ini yaitu Total Pembiayaan, Aset Lancar, Pendapatan Lainnya.

Hasil penelitian menjelaskan bahwa hanya ada satu bank yang mencapai efisiensi 100\% secara konsisten mulai tahun 2010-2014, yaitu Bank Maybank Syariah, dan terdapat satu bank yang tidak pernah mencapai efisiensi sempurna yaitu Bank Rakyat Indonesia Syariah, sementara tingkat efisiensi pada sembilan bank yang lain mengalami fluktuasi. Fenomena menarik juga terjadi pada UUS, terdapat satu bank yang mencapai efisiensi sempurna secara konsisten yaitu Bank Permata, dan dua bank yang selalu inefisien yaitu Bank Danamon dan BPD Riau, sementara gejolak efisiensi juga dialami pada sembilan UUS yang lain. Nilai efisiensi yang ditemukan juga menunjukkan bahwa secara umum perbankan syariah di Indonesia tidak terpengaruh imbas krisis suprime mortgage 2008.

Penelitian lain dilakukan oleh Puspita (2017) meneliti efisiensi BPD syariah di Indonesia pada periode 2012-2016. Metode yang digunakan pada penelitian ini yaitu DEA. Sementara pengukuran efisiensi yang digunakan yaitu dengan pendekatan dari sisi teknis. Variabel input yang digunakan yaitu ukuran bank, Return on Assets (RoA), Net Performing Loan (NPF) dengan output yang digunakan total pembiayaan dan inflasi. Selain menggunakan DEA, peneliti juga menggunakan regresi tobit dalam meneliti faktor-faktor mana yang mempengaruhi tingkat efisiensi BPD tersebut.

Pada penelitian tersebut didapatkan hasil, rata-rata efisiensi BPD Syariah berada di kisaran $80 \%$. Dari penggunaan regresi Tobit, diketahui bahwa variabel ukuran bank, RoA, Total pembiayaan berpengaruh terhadap tingkat efisiensi BPD Syariah di Indonesia. Sementara variabel tingkat kredit macet dan inflasi tidak berpengaruh signifikan.

Penelitian yang mirip juga dilakukan oleh Cahyono dan Rani (2017) yaitu tentang UUS BPD di pulau Sumatera. Namun perbedaanya terletak pada penggunaan variabel input yang digunakan yaitu beban operasional, beban tenaga kerja, beban lainnya dan beban dana usaha, Sementara output yang digunakan yaitu tingkat pendapatan. Hasil pengukuran efisiensi menunjukkan, mayoritas kinerja UUS cukup baik yaitu berada di atas $90 \%$. 
Berdasarkan review di atas, penelitian yang dilakukan Puspita (2017) serta Cahyono dan Rani (2017) memiliki kesamaan tujuan yang ingin dicapai peneliti. Hasil penelitian tersebut menjadi rujukan untuk melakukan pengukuran lanjutan dengan menggunakan periode data yang lebih terbaru guna mengetahui apakah kinerja UUS BPD di Indonesia masih cukup baik atau sebaliknya.

\section{METODE PENELITIAN}

Pada penelitiaan ini, pengukuran efisiensi akan menggunakan pendekatan efisiensi teknis dengan alat analisis yang digunakan yaitu Data Envelopment Analysis (DEA). Populasi yang digunakan yaitu 18 UUS BPD di Indonesia. Namun, adanya keterbatasan data maka peneliti hanya menggunakan 12 UUS BPD . Berikut sampel yang peneliti gunakan:

Tabel 2. Sampel Penelitian

\begin{tabular}{clc}
\hline No. & \multicolumn{1}{c}{ Sampel } & Daerah Asal \\
\hline 1. & UUS Bank DKI & DKI Jakarta \\
\hline 2. & UUD Bank BPD Yogyakarta & Yogyakarta \\
\hline 3. & UUS Bank BPD Jawa Tengah & Jawa Tengah \\
\hline 4. & UUS Bank BPD Jawa Timur & Jawa Timur \\
\hline 5. & UUS Bank BPD Sumatera Utara & Sumatera Ytara \\
\hline 6. & UUS Bank BPD Sumatera Barat & Sumatera Barat \\
\hline 7. & UUS Bank BPD Riau & Riau \\
\hline 8. & UUS Bank BPD Sumatera Selatan & Sumatera Selatan \\
\hline 9. & UUS Bankka Belitung & Kalimantan Selatan \\
\hline 10. & UUS Bank BPD Sulawesi Selatan & Sulawesi Selatan \\
\hline 11. & UUS Bulawesi Barat & Barat. \\
\hline 12. & UUS Bank Jambi & Nusa Tenggara Barat \\
\hline
\end{tabular}

Setelah menentukan sampel, maka langkah selanjutnya peneliti menentukan variabel input dan output yang digunakan. Merujuk pada penelitian yang dilakukan oleh Ascarya dan Yumanita (2006), Abidin dan Endri (2009), Firdaus dan Hosen (2013), Rosman, Wahab, \& Zainol (2014), Puspita (2017) maka variabel yang digunakan pada Tabel 3,

Periode data yang digunakan pada penelitian bersifat bulanan dari tahun 2012 hingga 2017 bersumber dari laporan keuangan yang diterbitkan oleh Bank serta laporan bulanan yang diterbitkan di situs Bank Indonesia (BI). Penggunaan periode data tersebut, dengan mempertimbangkan 
ketersediaan data serta historis waktu yang cukup panjang sehingga hasil pengolahan data akan lebih valid dan bisa dipertanggungjawabkan.

Tabel 3. Variabel Input dan Output

\begin{tabular}{lcc}
\hline No & Variabel & Kategori \\
\hline 1. & DPK & Input \\
\hline 2. & Biaya Tenaga Kerja & Input \\
\hline 3. & Total Pembiayaan & Output \\
\hline 4. & Penempatan di Bank Lain & Output \\
\hline
\end{tabular}

Pengukuran efisiensi didukung dengan metode regresi tersebut membantu peneliti untuk mengidentifikasi variabel-variabel yang berpengaruh terhadap efisiensi suatu UUS. Jenis regresi yang digunakan adalah regresi tobit. Alasannya, dependen yang digunakan peneliti memiliki nilai terbatas, dimana skor efisiensi terdiri dari 0 -1. Sementara untuk variabel independen, peneliti menggunakan variabel total simpanan, biaya tenaga kerja, total pembiayaan dan penempatan bank lain. Secara keseluruhan, hal tersebut peneliti gambarkan dalam bentuk model sebagai berikut :

$$
\mathrm{E}_{\mathrm{UUS}}=\mathrm{a}+\mathrm{b}_{1} \log \mathrm{TS}+\mathrm{b}_{2} \log \mathrm{BTK}+\mathrm{b}_{3} \log \mathrm{TP}+\mathrm{b}_{4} \log \mathrm{PBL}+\varepsilon_{n}
$$

Dimana E adalah skor efisiensi dari UUS, TS adalah Total Simpanan (DPK), BTK adalah Biaya Tenaga Kerja, TP adalah Total Pembiayaan, dan PBL adalah Penempatan di Bank Lain.

Selain itu, peneliti juga menyusun hipotesa awal sebagai landasan dalam menilai signifikansi suatu variabel independen terhadap variabel dependen. Rumusan hipotesa yang digunakan yaitu :

Hipotesa $\mathrm{Nol}\left(\mathrm{H}_{\mathrm{O}}\right) \quad$ : jika nilai probabilitas (p) lebih kecil dari nilai alpha $(\alpha)$ maka variabel independent berpengaruh signifikan terhadap efisiensi UUS BPD di Indonesia.

Hipotesa Alternatif $\left(\mathrm{H}_{\mathrm{a}}\right)$ : jika nilai probabilitas $(\mathrm{p})$ lebih besar dari nilai alpha $(\alpha)$ maka variabel independen tidak berpengaruh signifikan terhadap efisiensi UUS BPD di Indonesia.

\section{HASIL DAN PEMBAHASAN}

\subsection{HASIL EFISIENSI}

Tabel 4 memperlihatkan tingkat efisiensi rata-rata UUS tertinggi terjadi pada tahun 2016, dimana skor efisiensi mencapai 97,6 persen. Sementara skor terendah terjadi pada tahun 2013 yaitu sebesar 85,2 persen.

Tingginya skor efisiensi pada tahun 2016, salah satunya didorong oleh banyak UUS yang mampu mencapai skor efisiensi sempurna yaitu 100 
persen. Hanya UUS Bank Jambi yang tidak meraih skor sempurna, karena hanya mendapat nilai 78,3 persen. Di sisi lain, rendahnya rata-rata skor efisiensi di tahun 2013 terjadi akibat hanya beberapa UUS yang mendapat skor efisiensi sempurna. Bahkan pada periode ini, terdapat UUS yang mendapatkan nilai skor efisiensi hanya sebesar 28,2 persen.

Tabel 4. Hasil Pengolahan Efisiensi UUS (persen)

\begin{tabular}{|c|c|c|c|c|c|c|c|}
\hline No & Nama & 2012 & 2013 & 2014 & 2015 & 2016 & 2017 \\
\hline 1 & BPD Jogja & 83,3 & 100 & 96,8 & 100 & 100 & 100 \\
\hline 2 & $\begin{array}{l}\text { BPD } \\
\text { Kaltim }\end{array}$ & 100 & 99,9 & 100 & 83,6 & 100 & 83,5 \\
\hline 3 & Bank DKI & 100 & 100 & 80,1 & 95 & 100 & 100 \\
\hline 4 & Bank Jambi & 100 & 28,2 & 100 & 100 & 78,3 & 96,7 \\
\hline 5 & $\begin{array}{l}\text { Bank } \\
\text { Sulselbar }\end{array}$ & 100 & 82,3 & 67,6 & 100 & 100 & 100 \\
\hline 6 & $\begin{array}{l}\text { Bank Riau } \\
\text { Kepri }\end{array}$ & 100 & 94,2 & 100 & 100 & 100 & 100 \\
\hline 7 & $\begin{array}{l}\text { Bank } \\
\text { Sumbar }\end{array}$ & 74,0 & 81,5 & 88,3 & 99,5 & 100 & 100 \\
\hline 8 & $\begin{array}{l}\text { Bank } \\
\text { Jateng }\end{array}$ & 100 & 92,2 & 100 & 100 & 100 & 100 \\
\hline 9 & Bank Jatim & 85,2 & 100 & 100 & 93,3 & 100 & 100 \\
\hline 10 & $\begin{array}{l}\text { Bank } \\
\text { Kalsel }\end{array}$ & 100 & 92,7 & 98,7 & 100 & 100 & 88,5 \\
\hline 11 & $\begin{array}{l}\text { Bank } \\
\text { Sumsel } \\
\text { Babel }\end{array}$ & 100 & 72 & 100 & 100 & 100 & 100 \\
\hline 12 & $\begin{array}{l}\text { Bank } \\
\text { Sumut }\end{array}$ & 88,4 & 72,1 & 86,2 & 100 & 100 & 100 \\
\hline & Mean & 94.1 & 85.2 & 93.1 & 96,8 & 97,6 & 97 \\
\hline
\end{tabular}

Jika kita lihat di periode lain seperti tahun 2012, skor efisiensi ratarata mencapai 94,1 persen. Pencapaian ini didukung karena hanya empat UUS yang tidak memiliki skor efisiensi sempurna. Ini juga terlihat pada periode tahun lainnya seperti 2015 dan 2017. Sementara pada tahun 2014, skor efisiensi rata-rata masih cukup tinggi. Namun, disebabkan salah satu UUS yaitu UUS Bank Sumbar meraih skor sebesar 67,6 persen, maka berdampak terhadap pencapaian yang tidak setinggi pada tahun 2012, 2015 atau 2017.

Untuk mengidentifikasi faktor-faktor mana yang berpengaruh terhadap efisiensi suatu UUS, maka peneliti akan menggunakan metode Regresi Tobit. Hasil ini akan membantu peneliti dalam menganalisis hal yang berpengaruh signifikan terhadap nilai efisiensi. 


\subsection{HASIL REGRESI TOBIT}

Untuk mengidentifikasi variabel apa yang dapat mempengaruhi tingkat efisiensi UUS BPD di Indoneia, maka peneliti akan menggunakan metode regresi tobit. Elaborasi faktor-faktor yang mungkin berpengaruh terhadap skor efisiensi suatu UUS, peneliti lakukan dengan menggunakan pendekatan regresi tobit. Hasil pengolahan data akan membantu peneliti dalam mengidentifikasi faktor-faktor yang signifikan maupun tidak sehingga membantu analisis penyebab pergerakan efisiensi UUS di Indonesia.

Tabel 5. Hasil Regresi Tobit

\begin{tabular}{|c|c|c|c|c|}
\hline & DPK & BTK & $\mathrm{TP}$ & PBL \\
\hline UUS BPD di Indonesia & $0.00 *$ & $0.43^{*}$ & $0.00 *$ & $0.13^{*}$ \\
\hline
\end{tabular}

Dalam mengidentifikasi variabel-variabel mana yang mempengaruhi, maka peneliti menggunakan indikator nilai probabilitas dari masing-masing variabel. yang akan dibandingkan dengan nilai alpha yang digunakan yaitu $5 \%$. Berdasarkan hasil probabilitas yang terdapat dalam table 4.2, diketahui bahwa hanya DPK dan total pembiayaan yang signifikan terhadap tingkat efisiensi UUS BPD di Indonesia. Sementara variabel biaya tenaga kerja dan penempatan pada bank lain tidak berpengaruh signifikan.

Pengaruh signifikan variabel DPK terhadap skor efisiensi sejalan dengan temuan Gishkori dan Ullah (2013). Sementara pengaruh signifikan variabel total pembiayaan terhadap efisiensi dengan hasil penelitian Puspita (2017). Pengaruh dari masing-masing variabel terhadap kinerja bank tergambarkan dari proses bisnis yang dijalankan. Saat bank melakukan penghimpunan dana dari masyarakat lalu disalurkan ke perbankan, maka hal tersebut akan berpengaruh terhadap kinerja bank misalnya keuntungan yang didapatkan atau peningkatan total aset.

Jika kita mengambil contoh UUS BPD yang memiliki nilai efisiensi rendah seperti Bank Jambi di tahun 2013. Penyebab utamanya adalah tingginya DPK yang dikumpulkan tidak mampu dikonversikan menjadi jumlah pembiayaan yang cukup besar. Sementara jika lihat UUS BPD yang mampu mendapatkan skor efisiensi hingga 100\%, realisasi pembiayaan yang disalurkan cukup besar sejalan dengan penghimpunan DPK yang tinggi. Maka, bank perlu menyeimbangkan antara penerimaan sumber pendanaan dengan total penyaluran pembiayaan. Jika bank memiliki DPK yang tinggi namun tidak maksimal disalurkan dalam bentuk pembiayaan, secara pendekatan efisiensi akan mendapatkan hasil yang buruk dan begitu juga sebaliknya.

Oleh sebab itu, para manajemen bank perlu lebih giat dalam mengelola sumber daya yang ada untuk disalurkan dalam bentuk pembiayaan. Di sisi lain, target penyaluran pembiayaan yang ditetapkan juga perlu disertai dengan perencanaan segmen yang ingin dioptimalkan dan 
mitigasi terhadap resiko pembiayaan. Hal ini untuk mencegah tingkat pembiayaan macet bank meningkat tajam akibat tingginya nilai pembiayaan yang disalurkan.

\section{KESIMPULAN}

Berdasarkan hasil analisis, diketahui bahwa beberapa UUS BPD di Indonesia memiliki skor efisiensi yang cukup baik. Di sisi lain, masih terdapat UUS yang memiliki skor efisiensi yang kurang baik. Hasil identifikasi dengan menggunakan metode regresi Tobit, variabel yang berpengaruh signifikan terhadap skor efisiensi adalah DPK dan Total Pembiayaan. Hal ini tergambar pada beberapa sampel UUS yang mendapat skor efisiensi sempurna, karena mampu mengkonversi DPK menjadi pembiayaan secara optimal.

Beberapa saran yang peneliti usulkan dalam penelitian ini untuk meningkatkan efisiensi dari UUS di Indonesia, Pertama, memaksimalkan prinsip GCG untuk mendorong kinerja dari UUS. Pada konteks ini, peran regulator diantaranya OJK cukup penting. Sebagai otoritas perbankan dari sisi regulasi, OJK dapat lebih menyempurnakan POJK Nomor 8/POJK.03/2014 agar tidak hanya membahas dari sisi kesehatan bank, namun juga perbaikan internal lainnya yang harus dilakukan bank syariah. Selain itu, OJK perlu sering melakukan pertemuan rutin dengan para banker UUS BPD untuk mengetahui bagaimana sebenarnya masalah di lapangan, apa saja hambatan yang mereka temui sehingga bisa dicarikan jalan keluar yang sesuai dan mampu membantu peningkatan kinerja dari UUS itu sendiri.

Kedua, Optimalisasi peran OJK di daerah dalam melakukan kontrol terhadap UUS BPD di Indonesia. Kurangnya monitoring bisa jadi salah satu penyebab kinerja suatu UUS terganggu sehingga ikut berpengaruh terhadap pencapaian tingkat efisiensi yang didapatkan. Oleh karena itu, dengan keberadaan kantor wilayah OJK di daerah seharusnya lebih dapat melakukan monitoring secara intens sehingga jika ada gangguan yang dihadapi oleh UUS BPD di daerah dapat segera terselesaikan dan tidak menganggu perkembangan dari UUS itu sendiri. OJK bisa memanfaatkan era teknologi untuk memantau kinerja suatu UUS BPD di daerah. Misalnya melalui pemantauan data perbankan untuk mengetahui bagiamana kinerja bank tersebut apakah ada potensi kredit macet atau terjadi perlambatan ekonomi di daerah tersebut yang ditandai menurunnya total pembiayaan.

Ketiga, OJK dapat mempertimbangkan aturan yang memperbolehkan merger antar Bank Pembiayaan Rakyat Syariah (BPRS) dengan UUS BPD atau merger antar sesame UUS BPD di Indonesia untuk menciptakan industri UUS BPD yang lebih kuat dan siap menghadapi era persaingan perbankan yang ketat. Saat ini, banyak stakeholder yang menyuarakan agar UUS BPD melakukan merger agar mampu bersaing baik dari sisi permodalan maupun market share dengan perbankan nasional utamanya bank BUMN seperti Bank Mandiri, Bank BNI hingga Bank BRI.Bank-bank tersebut saat ini telah menjangkau hingga pelosok-pelosok daerah sehingga membuat market share dari BPD pun ikut berkurang. Dengan adanya keterbatassan dana dan sumber 
daya manusia serta teknologi tentu akan menyulitkan UUS BPD untuk mengikuti persaingan tersebut Salah satu jalan yang bisa dilakukan melalui melakukan merger antar BPRS dan UUS BPD atau merger antar sesama UUS BPD di Indonesia. Situasi ini tentu memperkuat tidak hanya dari sisi permodalan maupun sumber daya manusia namun juga dari market share yang ada di lapangan.

Keempat, perlu adanya dukungan dari pemerintah untuk meningkatkan kinerja bisnis UUS BPD di Indonesia misalnya bantuan anggaran daerah baik misalnya melalui skema pembelian saham. Hal ini sangat berharga bagi para UUS BPD untuk menunjang bisnis mereka lebih baik lagi dan ikut meningkat keuntungan yang didapat. Bantuan lain yang dapat diberikan misalnya melalui himbauan penerbitan obligasi oleh para UUS BPD. Penerbitan obligasi dimaksudkan untuk membantu suatu perusahaan mendapat modal tambahan guna melakukan ekspansi usaha yang lebih besar lagi. Saat ini penerbitan obligasi oleh UUS BPD masih jarang dilakukan sehingga cara ini mungkin bisa menjadi alternatif ketika UUS BPD mengalami masalah dari sisi permodalan. Pemerintah dapat membantu penerbitan obligasi tersebut baik sebagai Spesial Purpose Vehicle (SPV). SPV merupakan badan hukum yang bertugas untuk menerbitan obligasi termasuk obligasi syariah. Jika ada UUS yang hendak menambah permodalan melalui penerbitan obligasi syariah/sukuk, maka pemerintah dapat berkontribusi dengan membantu kelancaran penjualan tersebut sebagai SPV

Kelima, perlunya menggandeng UUS BPD dalam menyalurkan program-program bantuan pemerintah. Sebagai contoh program KUR. Program ini sudah lama ada di Indonesia, namun pemerintah masih menggandeng bank-bank besar terutama BUMN. Padahal keberadaan BPD termasuk UUS seharusnya mampu dimaksimalkan dalam melakukan penyaluran tersebut. Keberadaan mereka di daerah tentu mempermudah dalam menjangkau calon nasabah yang tepat sasaran sehingga program pemerintah berhasil Di sisi lain, hal ini juga ikut membantu UUS BPD memperluas market share mereka hingga ke pelosok-pelosok daerah sehingga mereka dapat meningkatkan total output yang disalurakan yaitu total pembiayaan. Meningkatnya total pembiayaan tentu dapat membantu peningkatan tingkat efisiensi teknis bank.

Keenam, mendorong UUS BPD untuk melakukan spin off dari induk dan melakukan listing saham di pasar saham. Sudah saat UUS BPD tidak selalu bergantung kepada induk dalam hal permodalan. Jalan alternatif yang dapat dilakuakan dengan melakukan listing saham guna mendapatkan dana tambahan dari investor. Saat ini pasar saham Indonesia sedang memiliki angin cerah yang ditandai indeks yang telah menembus di atas 6.000. Kondisi yang sedang baik ini perlu dimanfaatkan oleh UUS BPD dengan melakukan listing saham sehingga mudah menemukan investor. UUS BPD pun tidak terlalu direpotkan dengan masalah administrasi, hanya saja para UUS tersebut perlu memiliki laporan yang transparan agar bisa dilihat oleh para investor. Seharusnya hal ini bukan menjadi masalah sulit asalkan para stakeholder terkait seperti direktur, manajer hingga para pegawai ikut serta 
mewujudkan perusahaan yang transparan dan akuntable untuk menarik minat investor untuk membeli saham mereka.

Beberapa rekomendasi tersebut diharapkan mampu meningkatkan kinerja UUS BPD kedepannya agar dapat memberikan value added bagi pengembangan keuangan syariah di Indonesia serta perekonomian daerah khususnya.

\section{DAFTAR PUSTAKA}

Cahya, A. R. K. (2015). Efisiensi kinerja bank umum syariah di Indonesia Tahun 2010 -2012 Menggunakan Data Envelopment Analysis (DEA). Economics Development Analysis Journal, 4(3), 223-232.

Cahyono, E. F., \& Rani, L. N. (2017). Performa Efisiensi Teknis Unit Usaha Syariah Bank Pembangunan Daerah di Pulau Sumatera. Human Falah, 4.

Edward, M. Y., \& Anwar, A. Z. (2015). Analisis Efisiensi Perbankan Syariah Di Indonesia Periode 2010-2013. Jurnal Dinamika Ekonomi Dan Bisnis, 12(1).

Endri, E., \& Abidin, Z. (2009). Kinerja efisiensi teknis bank pembangunan daerah: Pendekatan Data Envelopment Analysis (DEA). Jurnal Akuntansi Dan Keuangan, 11(1), 21-29.

Faisol, A., Zainuri, Z., \& Yuliati, L. (2015). Analisis Efisiensi Perbankan Syariah Di Indonesia Pascakrisis Finansial Global 2008 Dengan Pendekatan Data Envelopment Analysis (DEA). Jurnal Fakultas Ekonomi Universitas Jember.

Fathony, M. (2013). Analisis afisiensi perbankan nasional berdasarkan ukuran bank dengan pendekatan Data Envelopment Analysis (DEA. Finance and Banking Journal, 15(1).

Firdaus, F., \& Hosen, M. N. (2013). Efficiency of islamic banking using two stage approach of data envelopment analysis. Bulletin of Monetary, Economic and Banking, 16(2), 155-176.

Gishkori, M., \& Naeem, U. (2013). Tehnical efficiency of Islamic and commercial bank: evidence from Pakistan. IOSR Journal of Business and Management, 7(4).

Hartono, I., Djohar, S., \& Daryanto, H. K. (2008). Analisis Efisiensi BPR di Wilayah Jabodetabek dengan Pendekatan Data Envelopment Analysis". Jurnal Manajemen Dan Agribisnis, 5(2), 52-63.

Isik, I., \& Hassan, K. (2002). Cost and Profit Efficiency of the Turkish Banking Industri: An Empirical Investigation. Financial Review, 37(2), 257-279.

Puspita, H. (2017). Efisiensi Bank Pembangunan Daerah (BPD) Syariah di 
Indonesia dengan pendekatan two stage data envelopment analysis periode 2012-2016. Universitas Airlangga.

Putri, V. R., \& Lukviarman, N. (2008). Pengukuran Kinerja Bank Komersial dengan Pendekatan Efisiensi: Studi Terhadap Perbankan Go Public di Indonesia. Jurnal Akuntansi Dan Auditing Indonesia, 12(1).

Rosman, R., Wahab, N. A., \& Zainol, Z. (2014). Efficiency of Islamic banks during the financial crisis: An analysis of Middle Eastern and Asian countries. Pacific-Basin Finance Journal, 28, 76-90.

Sufian, F. (2007). The efficiency of Islamic banking industry: A nonParametric analysis with non-discretionay input variable. Islamic Economic Studies, 14(1), 53-78. https://doi.org/10.1108/08288660710779399

Tuzuhroh, F. (2014). Analisis Efisiensi Bank Umum Syariah Di Indonesia Periode 2010-2012. Jurnal Akuntansi AKUNESA, 2(3).

Yudistira, D. (2004). Efficiency in Islamic Banking: an Empirical Analysis of Eighteen Banks. Islamic Economic Studies, 12(1), 1-19.

Yumanita, D., \& Ascarya. (2006). Analisis Efisiensi perbankan syariah di Indonesia dengan Data Envelopment Analysis. Tazkia Islamic Finance Dan Business Review, VII.1(2). 